\title{
Decapod crustaceans from a marine tropical mangrove ecosystem on the Southern Western Atlantic, Brazil
}

Aurinete Oliveira Negromonte, Marina de Sá Leitão Câmara de Araújo and Petrônio Alves Coelho ${ }^{\dagger}$

Laboratório de Carcinologia, Museu de Oceanografia da Universidade Federal de Pernambuco (UFPE). Av. Arquitetura, s/n, Cidade Universitária, Recife, Pernambuco, Brazil. `in memoriam. E-mails: (AON) aurinetenegromonte@hotmail.com; (MSLCA) mslc.araujo@gmail.com

\section{Abstract}

The purpose of the present study was to investigate the biodiversity, relative abundance and frequency of decapod crustaceans in the marine mangrove ecosystem at Gaibu Beach, Pernambuco State, Brazil. A total of eight samples were taken: four in the rainy season (August 2010) and four in the dry season (February 2011), during spring low tides and according to the phases of the moon. In all, 352 decapods were sampled. These specimens belonged to 17 species, 14 genera and 13 families. Pachygrapsus transversus (Gibbes, 1850), P. gracilis (Saussure, 1858), Panopeus americanus Saussure, 1857 and Uca (Leptuca) leptodactyla Rathbun, 1898 were very frequent. The three latter species occurred in all samples. The most abundant species was $P$. americanus. The Shannon-Wiener index $\left(\mathrm{H}^{\prime}\right)$ showed that, in general, the diversity level was medium for all samples. However, the sample taken at the time of the new moon during the rainy season was classified as highly diverse. These results contribute to the knowledge of the decapod fauna inhabiting mangroves associated with fringe reefs.

Key words: Abundance, Decapoda, diversity, mangrove.

\section{Introduction}

The mangrove forest is a coastal ecosystem belonging to the transition zone between the land and the sea. It reflects strong tidal influence and is typical of tropical and subtropical regions (Schaeffer-Novelli, 1995). The mangrove ecosystem is considered one of the areas of the world with relatively high fertility, can provide valuable information about the dynamics of the littoral environment (Lacerda et al., 2006), and is one of the most important coastal ecosystems. This high fertility results from the influence of many factors, including the abundance of primary producers, tidal action, high nutrient input, rapid cycling and uninterrupted annual production (Ottmann et al., 1966).

In general, mangroves are associated with estuaries. However, certain estuaries do not support mangroves, a condition more common in temperate regions, as the Patos Lagoon, Rio Grande do Sul State, Brazil. Moreover, certain mangrove forests are not estuarine, as the Sueste mangroves of Fernando de Noronha Archipelago and those occurring along the shores of the Santa Cruz Channel, a U-shaped channel that separates Itamaracá Island from the continent, both of these sites located in Pernambuco State, Brazil (Coelho et al., 2004). Gaibu Beach, also in Pernambuco, is one of the rare cases on the Brazilian coast 
of mangroves occurring in association with a fringe reef. This site is an enclave protected by sandy reefs on the seashore, with Laguncularia racemosa C. F. Gaertn occurring as a dominant species. The area is under the influence of the Arrombado Stream (Rolim et al., 2002).

According to Aveline (1980), the invertebrate fauna of mangrove forests is composed primarily of decapod crustacean species. These organisms play a significant role in the dynamics of the mangroves. In addition to their role as important participants in the trophic web, certain crustaceans constantly excavate burrows in the mud to obtain shelter and to store food. By digging in the sediment, they transport organic matter from the underlying strata to the surface (Araújo and Maciel, 1977; Macintosh, 1988). The crustaceans also participate in the cycling of nutrients, controlling the remineralization of detritus in the forest (Robertson, 1991). The purpose of the present study was to investigate the biodiversity of decapod crustaceans inhabiting the marine mangrove at Gaibu Beach and to compare these findings with those of other studies in marine and estuarine areas.

\section{Material and Methods}

\section{Study area}

Gaibu Beach (Fig. 1) is located in the Municipality of Cabo de Santo Agostinho, southern Pernambuco, Brazil ( $8^{\circ} 19^{\prime} \mathrm{S}$ and $\left.34^{\circ} 56^{\prime} \mathrm{W}\right)$. According to the Köppen (1936) classification, the climate type is As', i.e., a tropical humid climate with rainy winters and dry summers. The annual mean temperature is $25^{\circ} \mathrm{C}$. The beach can be considered intermediate in structure, showing an area of open sea and another area, larger and protected by two fringe reefs, in the infralittoral and intertidal. The mangrove is located in front of the intertidal fringe (CPRH, 1999).

\section{Field procedures}

Samples were taken during the spring low tide. Four samples were taken during the rainy season (August 2010) and four during the dry season (February 2011). The four samples during a given season were taken during different phases of the moon. As a result, a total of eight samples were performed: rainy period new moon (RPNM), rainy period waxing moon (RPWXM), rainy period full moon (RPFM), rainy period waning moon (RPWNM), dry period new moon (DPNM), dry period waxing moon (DPWXM), dry period full moon (DPFM) and dry period waning moon (DPWNM).

The individuals were randomly sampled by two collectors in the substratum (with a garden shovel), under rocks, in trees and in the water (with a dipnet), including every microhabitat within the mangrove. The specimens were fixed in $70 \%$ alcohol. The abiotic data collected during the sampling included air and water temperatures, measured in situ with a digital thermometer, and salinity and $\mathrm{pH}$, determined from measurements of water samples in the laboratory.

\section{Laboratory procedures}

The $\mathrm{pH}$ was determined with a bench $\mathrm{pH}$ meter. The salinity was determined with the Mohr-Knudsen method (Strickland and Parsons, 1972).

The individuals in the sample were identified to the species level based on specialized literature, including Rathbun (1918; 1930), Chace (1972), Abele and Kim (1986), and Melo (1996; 1999).

\section{Statistical analyses}

The Student $t$ test was applied to analyze the significance of the differences $(\alpha=0.05)$ in each abiotic factor between the dry and rainy periods (Zar, 1999). The relative abundance (RA) of each species was obtained from the equation $R A=n 100 / N$ (where $\mathrm{n}=$ the number 

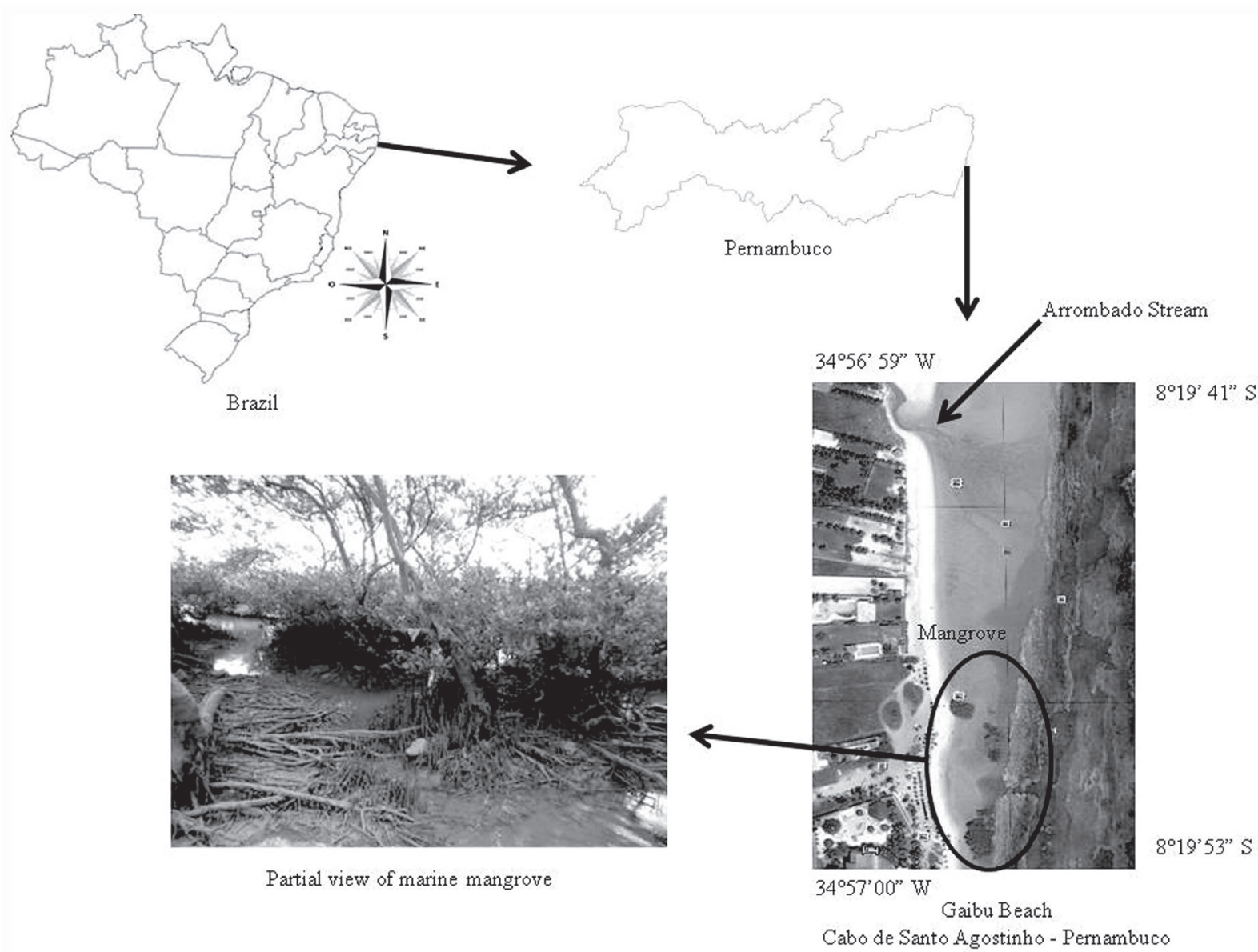

Figure 1. Map of the study area, the marine mangrove forest of Gaibu Beach, Pernambuco, Brazil.

of individuals of that species and $\mathrm{N}=$ the total number of individuals) and classified as dominant $(\geq 70 \%)$, abundant (40 to $70 \%)$, less abundant (10 to $40 \%)$ and rare $(\leq 10 \%)$.

The frequency of occurrence (FO) of each species was obtained from the equation $F O=$ a100/A (where $\mathrm{a}=$ number of samples containing the species and $\mathrm{A}=$ the total number of samples), with a posterior classification as very frequent ( $\geq 70 \%$ ), frequent (40 to $70 \%$ ), less frequent (10 to $40 \%)$ and sporadic ( $\leq$ $10 \%)$.

The following three ecological indexes were calculated: 1) Margalef (d), with values below 2.0 indicating areas of low diversity and values greater than 5.0 indicating areas of high diversity (Margalef, 1958); 2) Shannon-Wiener $\left(\mathrm{H}^{\prime} \log _{2}\right)$, classified as very low $\left(<1\right.$ bit.ind $\left.^{-1}\right)$, low ( 1 to 2 bits.ind $^{-1}$ ), medium ( 2 to 3 bits. ind $^{-1}$ ), high (3 to 4 bits.ind ${ }^{-1}$ ) and very high (> 4 bits.ind $^{-1}$ ) diversity (Shannon, 1948); and 3)
Pielou (J'), with values above 0.5 considered equitable (Pielou, 1969).

\section{Results}

Water temperature varied between 26.0 and $32.6^{\circ} \mathrm{C}\left(29.7 \pm 2.6^{\circ} \mathrm{C}\right)$ (Fig. $\left.2 \mathrm{~A}\right)$. The air temperature varied between 21.5 and $30.4^{\circ} \mathrm{C}\left(26.5 \pm 3.1^{\circ} \mathrm{C}\right)$ (Fig. 2A). Significant differences were detected in the water $(\mathrm{t}=$ -5.69; $p=0.01)$ and air temperature $(\mathrm{t}=-3.02$; $p=0.02$ ) between the rainy and dry periods. Both temperatures were higher during the dry period.

Salinity oscillated between 16.15 and 32.62 (28.63 \pm 5.30), but no significant difference was detected between the rainy and dry periods $(\mathrm{t}=0.02 ; p=0.44)$ (Fig. $2 \mathrm{~B})$. This pattern was also verified for the $\mathrm{pH}$, which varied between 7.60 and $8.19(7.88 \pm 0.24)$ 

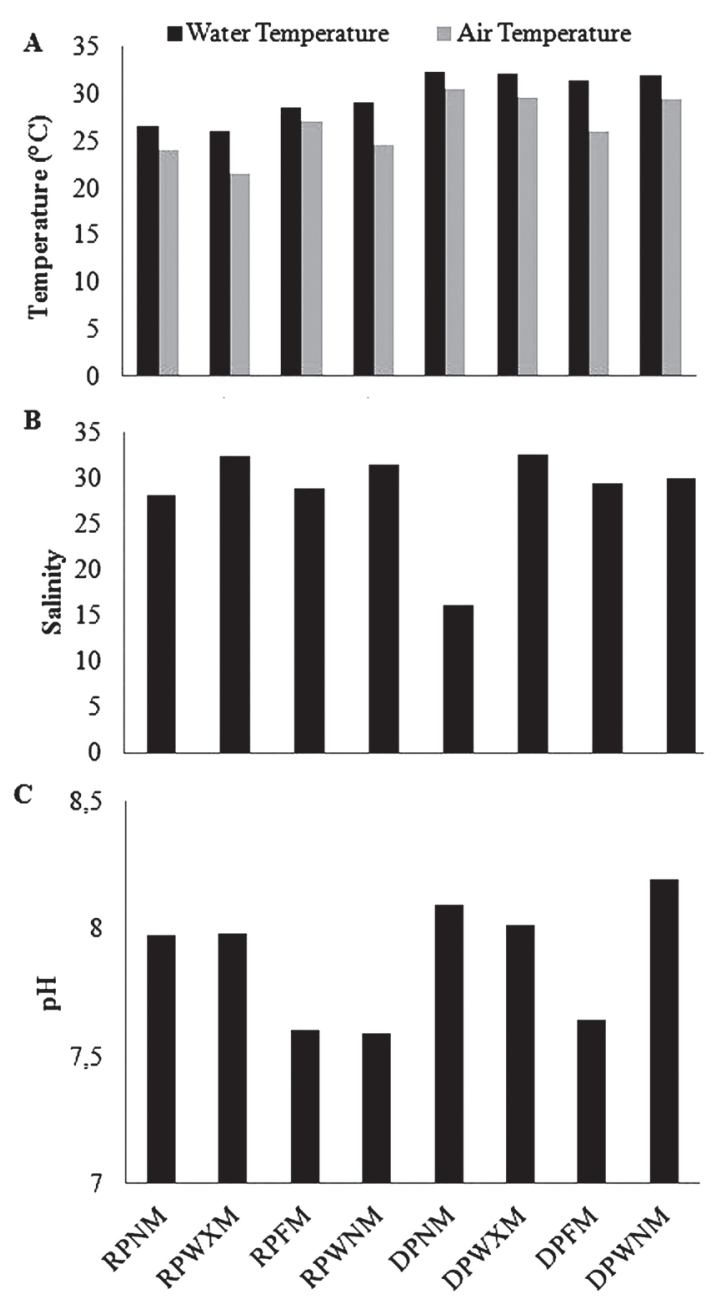

Figure 2. Values of (A) water and air temperatures, (B) salinity, (C) $\mathrm{pH}$ at the marine mangrove forest of Gaibu Beach, Pernambuco, Brazil.

(Fig. 2C) without any differences between the rainy and dry periods $(\mathrm{t}=-1.21 ; p=0.27)$.

A total of 352 decapods was sampled, including 17 species, 14 genera and 13 families. The group with the highest number of species was the Infraorder Brachyura Linnaeus, 1758, with 10 species, followed by the Infraorder Anomura MacLeay, 1838 and Infraorder Caridea Dana, 1852b (3 species each) and the Infraorder Axiidea Huxley, 1879 (1 species) (Tab. 1).

Pachygrapsus transversus (Gibbes, 1850), P. gracilis (Saussure, 1858), Panopeus americanus Saussure, 1857 and Uca (Leptuca) leptodactyla Rathbun, 1898 occurred very frequently, especially the three latter species, which were recorded in all samples (Tab. 2).
Table 1. List of the species sampled in the marine mangrove forest of Gaibu Beach, Pernambuco, Brazil.

\section{Infraorder Caridea Dana, 1852}

Palaemonidae Rafinesque, 1815 Palaemon northropi (Rankin, 1898)

Alpheidae Rafinesque, 1815 Alpheus cf. armillatus $\mathrm{H}$. Milne Edwards, 1837

Hippolytidae Spence Bate, 1888 Merguia rhizophorae (Rathbun, 1900)

Infraorder Axiidea Huxley, 1879

Upogebiidae Borradaile, 1903

Upogebia noronhensis FaustoFilho, 1969

Infraorder Anomura MacLeay, 1838

Porcellanidae Haworth, 1825

Petrolisthes armatus (Gibbes, 1850)

Diogenidae Ortmann, 1892 Clibanarius antillensis Stimpson, 1859

Clibanarius sclopetarius (Herbst, 1796)

Infraorder Brachyura Linnaeus, 1758

Majidae Samouelle, 1819

Microphrys bicornutus (Latreille, 1825)

Portunidae Rafinesque, 1815

Callinectes exasperatus

(Gerstaecker, 1856)

Callinectes marginatus (A. MilneEdwards, 1861)

Panopeidae Ortmann, 1893

Eurytium limosum (Say, 1818)

Panopeus americanus Saussure, 1857

Xanthidae MacLeay, 1838

Cataleptodius floridanus (Gibbes, 1850)

Grapsidae MacLeay, 1838

Pachygrapsus gracilis (Saussure, 1858)

Pachygrapsus transversus (Gibbes, 1850)

Sesarmidae Dana, 1851

Aratus pisonii (H. Milne

Edwards, 1853)

Ocypodidae Rafinesque, 1815

Uca (Leptuca) leptodactyla

Rathbun, 1898 
Table 2. Frequency of occurrence (FO) and relative abundance (RA) of decapod crustacean species in the marine mangrove forest of Gaibu Beach, Pernambuco, Brazil.

\begin{tabular}{lcccc}
\hline Species & FO & Classification & RA & Classification \\
\hline Alpheus cf. armillatus & 37.5 & less frequent & 1.42 & rare \\
Aratus pisonii & 37.5 & less frequent & 0.85 & rare \\
Callinectes exasperatus & 12.5 & less frequent & 0.28 & rare \\
Callinectes marginatus & 37.5 & less frequent & 0.85 & rare \\
Cataleptodius floridanus & 50 & frequent & 0.27 & rare \\
Clibanarius antillensis & 12.5 & less frequent & 0.57 & rare \\
Clibanarius sclopetarius & 62.5 & frequent & 2.56 & rare \\
Eurytium limosum & 12.5 & less frequent & 0.28 & rare \\
Merguia rhizophorae & 25 & less frequent & 1.42 & rare \\
Microphrys bicornutus & 12.5 & less frequent & 0.28 & rare \\
Pachygrapsus gracilis & 100 & very frequent & 11.08 & less abundant \\
Pachygrapsus transversus & 75 & very frequent & 5.68 & rare \\
Palaemon northropi & 25 & less frequent & 4.55 & rare \\
Panopeus americanus & 100 & very frequent & 47.73 & abundant \\
Petrolisthes armatus & 12.5 & less frequent & 0.85 & rare \\
Uca (Leptuca) leptodactyla & 100 & very frequent & 19.03 & less abundant \\
Upogebia noronhensis & 12.5 & less frequent & 0.28 & rare \\
\hline
\end{tabular}

In contrast, five species [Callinectes exasperatus (Gerstaecker, 1856), Clibanarius antillensis Stimpson, 1859, Eurytium limosum (Say, 1818), Microphrys bicornutus (Latreille, 1825) and Upogebia noronhensis Fausto-Filho, 1969] occurred only in one sample and were considered less frequent. The other species were considered frequent, and no species occurred sporadically.

Only one species (P. americanus) was relatively abundant (Tab. 2), whereas $U$. (L.) leptodactyla and $P$. gracilis were relatively less abundant. The other species were considered rare, and no species was dominant.

According to the Shannon-Wiener index $\left(\mathrm{H}^{\prime}\right)$, the diversity was medium for all samples except for the RPNM sample, which was classified as high in diversity. The values of the Pielou index (J') were greater than 0.5 and equitable in all samples. The Margalef index (d) was lower for the RPWNM (2.17) and higher for the RPNM (3.65), indicating a medium-diversity area (Tab. 3).
Table 3. Ecological indices: monthly values of Margalef (d), Pielou (J') and Shannon-Wiener ( $\mathrm{H}^{\prime}$ ) indices obtained for the four phases of the moon during the rainy and dry periods in the marine mangrove forest of Gaibu Beach, Pernambuco, Brazil.

\begin{tabular}{clccc}
\hline Period & Moon & $\mathrm{d}$ & $\mathrm{J}^{\prime}$ & $\mathrm{H}^{\prime}\left(\log _{2}\right)$ \\
\hline \multirow{4}{*}{ Rainy } & New & 3.654 & 0.921 & 3.301 \\
& Waxing & 2.274 & 0.920 & 2.582 \\
& Full & 2.963 & 0.895 & 2.836 \\
& Waning & 2.174 & 0.955 & 2.681 \\
& New & 2.357 & 0.912 & 2.561 \\
\multirow{4}{*}{ Dry } & Waxing & 2.215 & 0.903 & 2.536 \\
& Full & 2.626 & 0.888 & 2.664 \\
& Waning & 2.970 & 0.890 & 2.821 \\
\hline
\end{tabular}

Discussion

The water and air temperatures varied significantly between periods but showed only small oscillations among the samples. In the mangroves at Itamaracá Island, Pernambuco, 
the temperatures similarly showed no substantial variation (Macedo et al., 1973; Araújo et al., 2012), a characteristic typical of tropical regions. At Enseada dos Corais Beach, located near the study area, the salinity was found to range between 9 and 36 (Florêncio, 2000), whereas the salinity at the mangrove of Gaibu Beach varied between 16.15 and 32.62, indicating a more saline and stable system. The samples obtained during the dry season showed a large decrease in salinity. According to SINDA (2012), an intense rainfall occurred on the day prior to this sample. The $\mathrm{pH}$ values were always alkaline, as previously observed by Araújo et al. (2012).

Several authors have previously investigated the diversity of decapods in estuarine mangroves. The species richness found at Gaibu Beach was lower than the richness previously found for these other localities (Tab. 4). This lower diversity may be linked to the location of this study in a non-estuarine area. This location could be unsuitable for many species typical of estuarine mangroves, as Ucides cordatus (Linnaeus, 1763), Sesarma rectum Randall, 1840 and Goniopsis cruentata (Latreille, 1803), adapted to the variations occurring in the estuarine environment, including salinity, turbidity, and the type of substrate. Note that each locality can present their peculiar microhabitats and the sampling efforts in each study may have been different, which may also account for the different diversity among estuaries.

The Ocypodidae Rafinesque, 1815 and Grapsidae MacLeay, 1838 are usually the most diverse decapod crustacean families in mangrove ecosystems (Coelho, 1966; Jones, 1984; Macintosh, 1988; von Prahl et al., 1990; Cobo et al., 1994; Oshiro et al., 1998; Hartnoll et al., 2002; Echeverría-Sáenz et al., 2003). In the present study, the Ocypodidae were represented by a single species, Uca (L.) leptodactyla. Despite the annual oscillation in the temperature, this species was frequent and present in all samples. This finding shows that temperature is not a limiting factor for this eurythermic species. Similarly, Masunari (2006) observed this species in an area with a relatively broad range of temperature (13 to $35^{\circ} \mathrm{C}$ ). In addition, $U$. (L.) leptodactyla prefers high salinities (Crane, 1975; Barnwell, 1986; Thurman, 1998) and muddy sand substrata (Colpo and Negreiros-Fransozo, 2003; Benetti and Negreiros-Fransozo, 2004; Castiglioni and Negreiros-Fransozo, 2004), as observed in the present study, showing that the studied marine mangrove location has ideal characteristics as a habitat for this species. The family Grapsidae was represented by two very frequent but non-abundant species, Pachygrapsus transversus and $P$ gracilis. These species were rare and less abundant, respectively. Note that this mangrove forest is protected by a fringe reef and that this reef may provide a refuge for species that are difficult to sample, including those belonging to the genus Pachygrapsus Randall, 1840. For this reason, a more speciesspecific capture method should be applied to sample these crabs, as observed by Flores et al. (1998).

Panopeus americanus has normally been found in association with sandy-mud substrata (Masunari and Dubiaski-Silva, 1998), under stones, on muddy beaches and in mangroves (Melo, 1996), exactly the same habitats in which this species was found in this study. The finding that $P$. americanus was more abundant than the other species in the sample could be associated with the slow mobility of this species, which facilitated its capture.

In the samples, all the specimens of Callinectes exasperatus and C. marginatus (A. Milne-Edwards, 1861) (both members of the family Portunidae) were juveniles. For this reason, the marine mangrove ecosystem investigated in this study can be considered a nursery area for both species. Several papers have reported that juvenile Callinectes Stimpson, 1860 migrate to estuaries, where they find food and shelter from predation (Hines et al., 1987; Guerin and Stickle, 1997; Araújo et al., 2012). Although the Gaibu mangrove forest is not estuarine, it is protected by reefs. According to Melo (1996), C. exasperatus inhabits shallow waters from the intertidal to a depth of $8 \mathrm{~m}$ in the sea and in estuarine waters, near river mouths and in 
mangroves. Callinectes marginatus inhabits sandy and muddy bottoms, the periphery of mangroves, brackish water, and, rarely, open sea, from the intertidal to a depth of $25 \mathrm{~m}$. Due to these ecological preferences, the Gaibu mangrove forest is a suitable habitat for the development of the juveniles.

The value of $\mathrm{H}^{\prime}$ during the RPNM was the only one similar to that previously observed in the mangroves of the Caribbean $\left(\mathrm{H}^{\prime} \log _{2}=3.525\right)\left(\mathrm{J}^{\prime}=0.869\right)$ and of the Pacific coasts of Panama $\left(\mathrm{H}^{\prime} \log _{2}=3.704\right)\left(\mathrm{J}^{\prime}=0.857\right)$ (Abele, 1974), whereas the other samples of the present study showed lower values. During the rainy period, phytoplankton production is less intense (Passavante and Feitosa, 2004). This decrease in production could result in a decrease in the availability of food to the decapods and could thus reduce their abundance. However, the days are significantly shorter during the winter in the temperate zones (Brosche and Sündermann, 1990), and slightly shorter in tropical ones. This difference associated with the absence of light on new moon nights, reduces the risk of predation. For this reason, this community may be affected more strongly by the action of predators (top-down control) than by the amount of food available (bottomup control) (Uye and Liang, 1998). The results presented in this paper contribute to the knowledge of the decapod fauna inhabiting mangroves associated with fringe reefs, a rare and poorly studied habitat.

\section{Acknowledgements}

The authors thank Dr. Jesser Fidelis de Souza-Filho (UFPE), Dr. Luis Ernesto Arruda Bezerra (UFERSA) and Dr. Alexandre Oliveira de Almeida (UESC) for aid in the identification of the animals. The first author thanks the Universidade Federal de Pernambuco (UFPE) for a scholarship granted by the Program of Academic Maintenance. The second author thanks the Coordenação de Aperfeiçoamento de Pessoal de Nível Superior (CAPES) for a doctoral scholarship. We also thank our past supervisor and friend Dr. Petrônio Alves Coelho, in memoriam, for all his support and encouragement of our work on this study. From the inception of this undergraduate project to the analyses of the data, he was always available to help us. The authors are thankful for the suggestions offered by the anonymous referees on the first version of the manuscript and by the American Journal Experts for the English editing.

\section{References}

Abele, L.G. 1974. Species diversity of decapod crustaceans in marine habitats. Ecology, 55: 156-161.

Abele, L.G. and Kim, W. 1986. An Illustrated Guide to the Marine Decapod Crustaceans of Florida. Florida Department of Environmental Regulation, Technical Series, 8(1/2): 760p.

Almeida, A.O.; Coelho, P.A.; Santos, J.T.A. and Ferraz, N.R. 2006. Crustáceos decápodos estuarinos de Ilhéus, Bahia, Brasil. Biota Neotropica, 6(2): http://www. biotaneotropica.org.br/v6n2/pt/abstract?i nventory+bn03406022006 - ISSN 16760603.

Araújo, D.S.D. and Maciel, N.C. 1977. Os manguezais do Recôncavo da Baía de Guanabara; relatório preliminar. RJ, DECAM-DEPOL/FEEMA, v. 1 e 2, 195p.

Araújo, M.S.L.C.; Barreto, A.V.; Negromonte, A.O. and Schwamborn, R. 2012. Population ecology of the blue crab Callinectes danae (Crustacea: Portunidae) in a Brazilian tropical estuary. Anais da Academia Brasileira de Ciências, 84(1): 129138.

Aveline, L.C. 1980. Fauna de manguezais brasileiros. Revista Brasileira de Geografia, 42(2): 786-821.

Barnwell, F.H. 1986. Fiddler crabs of Jamaica (Decapoda, Brachyura, Ocypodidae, Genus Uca). Crustaceana, 50(2): 146-165.

Benetti, A.S. and Negreiros-Fransozo, M.L. 2004. Relative growth of Uca burgersi 
(Crustacea, Ocypodidae) from two mangroves in the southeastern Brazilian coast. Iheringia Série Zoologia, 94(1): 67-72.

Brosche, P. and Sündermann, J. 1990. Earth's Rotation from Eons to Days. Berlin, Springer, 345p.

Calado, T.C.S. and Sousa, E.C. 2003. Crustáceos do complexo estuarino-lagunar Mundaú/Manguaba Alagoas. Maceió, FAPEAL, 116p.

Castiglioni, D.S and Negreiros-Fransozo, M.L. 2004. Comparative analysis of the relative growth of Uca rapax (Smith) (Crustacea, Ocypodidae) from two mangroves in São Paulo, Brazil. Revista Brasileira de Zoologia, 21(1): 137-144.

Chace Jr., F.A. 1972. The shrimps of the Smithsonian-Bredin Caribbean expeditions with a summary of the West Indian shallow water species (Crustacea: Decapoda: Natantia). Smithsonian Contributions to Zoology, 98: 1-179.

Cobo, V.J.; Fransozo, A.; Mantelatto, F.L.; Pinheiro, M.A.A.; Santos, S. and Góes, J.M. 1994. Composição dos braquiúros (Crustacea, Decapoda) no manguezal formado pelos rios Comprido e Escuro, Ubatuba (SP). Anais do III Simpósio de Ecossistemas da costa Brasileira: subsídios a um gerenciamento ambiental, Publicação ACIESP, 87(1): 146-150.

Coelho, P.A. 1966. Os crustáceos decápodos de alguns manguezais pernambucanos. Trabalhos do Instituto Oceanográfico da Universidade Federal de Pernambuco, 7/8: 71-90. [Dated 1965/1966, published 1966]

Coelho, P.A.; Batista-Leite, L.M.A.; Santos, M.A.C. and Torres, M.F.A. 2004. O manguezal. p. 640-688. In: E. EskinaziLeça; S. Neumann-Leitão and M.F. Costa (eds),Oceanografia: Um cenário tropical. Recife, Bagaço.

Coelho-Santos, M.A. and Coelho, P.A. 2001. Crustacea Decapoda of the Paripe river estuary, Pernambuco, Brazil. Hydrobiologia, 449(1-3): 77-79.

Colpo, K.D. and Negreiros-Fransozo, M.L. 2003. Reproductive output of Uca vocator (Herbst, 1804) (Brachyura, Ocypodidae) from three subtropical mangroves in Brazil. Crustaceana, 76(1): 1-11.

CPRH. Companhia Pernambucana de Meio Ambiente. 1999. Diagnóstico SocioAmbiental do Litoral Sul de Pernambuco. 214p.

Crane, J. 1975. Fiddler crabs of the world, Ocypodidae: genus Uca. Princeton, University Press, 736p.

Echeverría-Saénz, S.; Vargas, R. and Wehrtmann, I.S. 2003. Diversity of decapods inhabiting the largest mangrove system in the Pacific of Costa Rica. Nauplius, 11(2): 91-97.

Ferreira, A.C. and Sankarankutty, C. 2002. Estuarine carcinofauna (Decapoda) of Rio Grande do Norte, Brazil. Nauplius, 10(2): 121-129.

Florêncio, M.A.P. 2000. Dinâmica populacional e produção secundária de Laeonereis acuta (Treadwell, 1923) na Praia de Enseada dos Corais - Cabo de Santo Agostinho Pernambuco - Brasil. Universidade Federal de Pernambuco, Recife, Brazil, Master Thesis. 69p. [Unpublished].

Flores, A.A.V.; Negreiros-Fransozo, M.L. and Fransozo, A. 1998. The megalopa and juvenile development of Pachygrapsus transversus (Gibbes, 1850) (Decapoda, Brachyura), compared with other grapsid crabs. Crustaceana, 71(2): 197-222.

Guerin, J.L. and Stickle, W.B. 1997. Effects of salinity on survival and bioenergetics of juvenile smaller blue crabs, Callinectes similis. Marine Biology, 129: 63-69.

Hartnoll, R.G.; Cannicci, S.; Emmerson, W.D.; Fratini, S.; Macia, A.; Mgaya, Y.; Porri, F.; Ruwa, R.K.; Shunula, J.P.; Skov, M.W. and Vannini, M. 2002. Geographic trends in mangrove crab abundance in East Africa. Wetlands Ecology and Management, 10: 203-213.

Hendrickx, M.E. 1984. Studies of the coastal marine fauna of southern Sinaloa, Mexico. II. The decapod crustaceans of Estero El Verde. Annales del Instituto de Ciencias del Mar y Limnología Universidad Nacional Autónoma de México, 11(1): 23-48. 
Hines, A.H.; Lipcius, R.N. and Haddon, A.M. 1987. Population dynamics and habitat partitioning by size, sex and molt stage of blue crabs Callinectes sapidus in a subestuary of Central Chesapeake Bay. Marine Ecology, 36: 55-64.

Jones, D.A. 1984. Crabs of the mangal ecosystem. p. 89-109. In: F.D. Por and I. Dor (eds), Hydrobiology of the Mangal. The Hague, Dr. W. Junk Publishers, 264p.

Köppen, W. 1936. Das geographisca System der Klimate. p. 1-44. In: W. Koppen and G. Geiger (eds), Handbuch der Klimatologie. Berlim, Borntraeger.

Lacerda, L.D.; Maia, L.P.; Monteiro, L.H.H.; Souza, G.M.E.; Bezerra, L.J.C. and Menezes, M.O.T. 2006. Manguezais do nordeste e mudanças ambientais. Revista Ciência Hoje, 229: 24-29.

Macedo, S.J.; Lira, M.E.F. and Silva, J.E. 1973. Condiçóes hidrológicas do Canal de Santa Cruz. Boletim de Recursos Naturais, 11: 55-92.

Macintosh, D.J. 1988. The ecology and physiology of decapods of mangrove swamps. Symposia of the Zoological Society of London, 59: 315-341.

Margalef, D.R. 1958. Information theory in ecology, General Systems, 3: 36-71

Masunari, S. 2006. Distribuição e abundância dos caranguejos $U c a$ Leach (Crustacea, Decapoda, Ocypodidae) na Baía de Guaratuba, Paraná, Brasil. Revista Brasileira de Zoologia, 23(4): 901-914.

Masunari, S. and Dubiaski-Silva, J. 1998. Crustacea Decapoda da praia rochosa da Ilha do Farol. Matinhos, Paraná. II. Distribuição espacial de densidade das populaçóes. Revista Brasileira de Zoologia, 15(3): 643-664.

Melo, G.A.S. 1996. Manual de Identificação dos Brachyura (Caranguejos e Siris) do Litoral Brasileiro. Sáo Paulo, Plêiade/ FAPESP, 604p.

Melo, G.A.S. 1999. Manual de identificação dos Crustacea Decapoda do litoral brasileiro: Anomura, Thalassinidea, Palinuridea, Astacidea. São Paulo, Plêiade/ FAPESP, 551 p.
Oshiro, L.M.Y.; Silva, R. and Silva, Z.S. 1998. Composição da fauna de braquiúros (Crustacea Decapoda) dos manguezais da Baía de Sepetiba-RJ. Nauplius, 6: 31-40.

Ottmann, F.; Okuda, T.; Cavalcanti, L.; Silva, O.C.A.; Araújo, J.V.A.; Coelho, P.A.; Paranaguá, M.N. and Eskinazi, E. 1966. Estudo de Barra das Jangadas. Parte V. Efeitos da poluição sobre a ecologia do estuário. Trabalhos do Instituto de Oceanografia da Universidade Federal de Pernambuco, 7/8: 7-16. [Dated 1965/1966, published 1966]

Passavante, J.Z.O. and Feitosa, F.A.N. 2004. Dinâmica da produtividade fitoplanctônica na zona costeira marinha. p. 425-439. In: E. Eskinazi-Leça; S. Neumann-Leitão and F. Costa (eds). Oceanografia: um cenário tropical. Recife, Bagaço.

Pielou, E.C. 1969. An introduction to mathematical ecology. New York, Wiley Interscience, 286p.

Rathbun, M.J. 1918. The grapsoid crabs of America. Bulletin of the United States National Museum, 97: 1-461.

Rathbun, M.J. 1930. The cancroid crabs of America of the families Euryalidae, Portunidae, Atelecyclidae, Cancridae and Xanthidae. Bulletin of United States National Museum, 152:1-609.

Robertson, A.I. 1991. Plant-animal interactions and the structure and function of mangrove forest ecosystems. Australian Journal of Ecology, 16: 433-443.

Rolim, M.I.M.; Passavante, J.Z.O.; Santiago, M.F.; Leão, B.M.; Honorato-Silva, M.; Lima, M.S.C. and Sá, F.C.N. 2002. O manguezal da praia de Enseada dos Corais (Cabo de Santo Agostinho - PE). In. Simpósio Brasileiro De Oceanografia, São Paulo, Brazil.

Schaeffer-Novelli, Y. 1995. Manguezal, Ecossistema entre a terra e o mar. São Paulo Caribbean Ecological Research, 64p.

SINDA. Sistema Nacional de Dados Ambientais. 2012. Available at: http:// www.sinda.crn2.inpe.br/PCD/historico/ consulta_pcdm.jsp. Accessed on 9 May 2012. 
Shannon, C.E. 1948. A mathematical theory of communication. Bulletin of System Technology Journal, 27: 379-423.

Strickland, J.D.H. and Parsons, T.R. 1972. A Practical Handbook of Seawater Analysis. Ottawa, Fisheries Research Board of Canada, 310p.

Thurman, C.L. 1998. Evaporative water loss, corporal temperature and distribution of sympatric fiddler crabs $(U c a)$ from south Texas. Comparative Biochemistry and Physiology A, 119(1): 279-286.

von Prahl, H.; Cantera, J.R. and Contreras, R. 1990. Manglares y hombres del Pacífico Colombiano. Colombia, Folio Ltda., 193p. Uye, S. and Liang, D. 1998. Copepods attain high abundance, biomass and production in the absence of large predators but suffer cannibalistic loss. In: Dahms, H.U., T. Glatzel, H.J. Hirche, S. Schiel \& H.K. Schminke, (eds.). Proceedings of the 6th International Conference on Copepoda. Journal of Marine Systems, Special Volume, 15(1-4): 495-501

Zar, J.H. 1999. Biostatistical Analysis. Upper Saddle River, Prentice-Hall, 662p. 